\title{
A Morphological Compounding Analysis of Hausa Registers Use in Nigerian Cell-phone Market
}

\author{
Almustapha Wali Sambo * \\ (National Institute for Nigerian Languages, Nigeria)
}

\begin{abstract}
This study aims to find the compound registers that are used among the Farm-Centre cell-phone marketers, analyse their compounding morphological structures, and explain the meaning they convey. The Farm-Centre Cell-phone Market is located in Kano metropolis, the largest city of Northern Nigeria. The study employs an ethnographic method of data collection and adopts Abubakar (2000) as a model of approach when analysing the structures of the compound registers. It is found that the registers have the following six morphological compound structures: (i) Genitive-based compounds $[\mathrm{LG}+\mathrm{N}]_{\mathrm{N}}$, (ii) Noun-based compounds $[\mathrm{N}+\mathrm{GL}+\mathrm{N}]_{\mathrm{N}}$, (iii) Adjective-based compounds $[\mathrm{Adj}+\mathrm{N}]_{\mathrm{N}}$, (iv) Diminutive-based compounds $[\mathrm{Dim}+\mathrm{N}]_{\mathrm{N}}$, (v) Particle dà 'with' compounds $[\mathrm{dà}+\mathrm{N}]_{\mathrm{N}}$, (vi) Verb-based compounds $[\mathrm{V}+\mathrm{VN} / \text { Prep }]_{\mathrm{V}}$. Moreover, the registers are so special among the marketers because they convey meanings that are irrelevant to the conventional meanings known by the general speakers of the Hausa language.
\end{abstract}

Keywords: Hausa, morphology, compounding, registers, meaning, Kano, Nigeria

\section{Introduction}

Hausa is a major language of West Africa with an estimated projection of over 50 million speakers. According to Ethnologue estimation, there are 41 million Hausa speakers (26,929,000 as first language (L1) speakers, while $15,000,000$ as second language (L2) speakers). It is a recognised language for business communication in West Africa. Therefore, this paper focuses on the professional use of the language among the marketers, focusing on the registers or terms used by the Farm-Centre Cell-phone Marketers in Kano, a northern and most populated state of Nigeria. The paper studies the structure and the meaning of the registers and does further detailed statistical research on it.

The structure of words and expressions in a language typically reveals recurring patterns of organization, which give speakers the resources to establish new forms based on the structure within the language. This study, therefore, seeks to explain the morphological

\footnotetext{
* Almustapha Wali Sambo: Assistant Lecturer, National Institute for Nigerian Languages, Aba, Abia State, 450101, Nigeria. E-mail: mustaphaoldman@gmail.com.
} 


\section{Almustapha Wali Sambo}

compounding processes of registers used by the members of Farm-Centre cell-phone marketers of Kano State, Nigeria, where they use certain words and phrases that have a different meaning compared to common terms used by the native speakers of the Hausa language. Registers, according to Wardhaugh (2006:52), "are sets of language items associated with discrete occupational or social groups. Surgeons, airline pilots, bank managers, sales clerks, jazz fans, and pimps employ different registers". Furthermore, Ferguson (1994:20) argued that, "people participating in recurrent communication situations tend to develop similar vocabularies, similar features of intonation, and characteristic bits of syntax and phonology that they use in these situations." Yule (2010:38) defined register as a convenient way of using language that is appropriate in a specific context, which may be identified as situational (e.g. in church), occupational (e.g. among lawyers) or topical (e.g. talking about language). He claims that one of the defining features of a register is the use of jargon, which is special technical vocabulary (e.g. plaintiff, suffix) associated with a specific area of work or interest. In social terms, jargon helps to create and maintain connections among those who see themselves as "insiders" in some way and to exclude "outsiders." Therefore, this study tries to analyse registers used by the group of cell-phone marketers of the Farm Centre market of Kano that have compounding features, namely, "compound registers". Compound registers may be defined as registers that have two or more items combined to form another register. In this paper, it is the compound word or expression that only "insiders" of the market will be able to understand.

Abraham (1941:13) was the first author to bring up the term "figurative compounds consisting of a verb and a noun." Gouffé (1965:12) was the first to coin "final vowel shortening", a feature closely associated with both compounding and naming in Hausa. Galadanci (1969:26, 1972:41) described the basic structures of Hausa compounds including verbal compounds - and the kinds of (nominal) phrases in which they appear. Ahmad (1994) was the first to devote a whole book to the subject of compounding in Hausa. Ahmad (1994:28) defined a Hausa compound as "a complex word that comprises two or more independent words and whose meaning is mostly non-compositional". He offered a second definition: "a group of words that behave morphosyntactically and semantically as a unit" (ibid: 28). Authors who have written about Hausa compounds accepted the formation - a verb and the following noun - as a compound rather than a lexicalized phrase. Many of these compounds have more than two members. Ahmad (1994:80) did not regard the number of words in a compound as significant: "No empirical evidence is found to suggest that the number of words per se is the critical factor in determining the function or behaviour of compounds." According to McIntyre (2006:15), compounds are non-referential. This criterion, as proposed by Spencer (1991:312) is true of 
Hausa verbal compounds since "the non-heads of compounds never refer to specific objects”. In the example hànà-sallà, sallàa is not specific and could not be substituted by the (feminine singular) pronoun $t a$ 'it'. Ahmad (1994:35) called this feature "substitution restriction". However, at another level, the criterion of "non-referentiality" does not apply to Hausa verbal compounds. The gender and number of Hausa compounds have been discussed by other authors (Galadanci, 1969:225; Ahmad, 1994:99; Newman, 2000:110; Jaggar, 2001:124). McIntyre (2006:17) summarised that "in principle, Hausa verbal compounds do not mark gender or number. Gender is assigned either pragmatically according to the gender of the person referred to in the compound - or by analogy." (Ahmad, 1994:99-110). The following example is pragmatic: tàttàbà-kunne (touch repeatedly ear) great-grandchild. If the referent (great-grandchild) is a boy, the compound is masculine; if the referent is a girl, the compound is feminine.

The methods employed in this study for collecting data include interviews and observations, as well as printed documents that served as a secondary source of data. This study adopted Abubakar's model of analysing compound words in Hausa. Abubakar (2000:11) postulated that "the study of morphology deals with word formation and inflection. Word formation is subdivided into two smaller sub-fields, one of which is concerned with the process of derivation and the other is of compounding. To form a word or derive other words from base form, one of the three morphological processes must be used". According to Abubakar (2000:77), there are two major categories of compounds in Hausa, namely, nominal and adverbial compounds. Nominal compounds are subdivided into four types, based on their components, as follows: (i) noun-based compounds (ii) verb-based compounds, (iii) adjectival-based compounds, and (iv) ideophone-based compounds. Adverbial Compounds have three types, namely: (i) simple adverbial compound (ii) adverbial cluster and (iii) adverbial phrase compounds. Below are some examples of how Abubakar categorises and analyses compounds in Hausa, which this study is going to follow when analysing compound registers used among Farm-Centre cell-phone marketers in Kano:

(a) Noun-based compounds

- sanyi-sanyii 'cold'

(Noun+Noun)

-kèeken-xinkiii 'sewing machine'

- màce-dà-gooyoo 'a type of button'

(Noun + Genitival Linker + Noun)

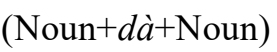

(b) Verb-based compounds

- gùtsùri-tsòomaa 'a piecemeal approach'

-kaa-fi-xaa-wùyaa 'a grandchild'

(Imperative Verb +Imperative Verb)

(Finite Verb based)

- rùuxà-kùyàngii 'twilight' (Imperative Verb +constituent other than the verb)

This is how the analysis of this study will be approached in the next section after 
presenting the hierarchical morphological structure of each compound register base.

Hausa is a tonal language with three surface tones: the high $(\mathrm{H})$ tone which is left unmarked (e.g. /a/), the low (L) tone indicated by a grave accent (e.g. /à/), and the falling (F) tone indicated by a circumflex (e.g. /â/). The notation of doubling a vowel (aa) to indicate a long vowel is used in this paper.

\section{Data presentation and analysis}

The most analysed compounds are those with $[\mathrm{N}+\mathrm{N}]$ and $[\mathrm{A}+\mathrm{N}]$ or $[\mathrm{N}+\mathrm{A}]$ internal structures, whereas many other structural types have almost been ignored. Little attention has been paid to a variety of formations, such as: $[\mathrm{A}+\mathrm{A}]$ (bitter-sweet), $[\mathrm{A}+\mathrm{N}]$ (Italian: giallolimone 'lemon yellow'), pronouns (self-determination), and particles (make up).

In addition to the aforementioned structures $\left([\mathrm{N}+\mathrm{N}]_{\mathrm{N}}\right.$ and $[\mathrm{A}+\mathrm{N}]_{\mathrm{N}}$ or $\left.[\mathrm{N}+\mathrm{A}]_{\mathrm{N}}\right)$, the following compound structures can also be found (as in the case with this study):
(i) Genitive-based compounds
$[\mathrm{LG}+\mathrm{N}]_{\mathrm{N}}$
(ii) Noun-based compounds
$[\mathrm{N}+\mathrm{GL}+\mathrm{N}]_{\mathrm{N}}$
(iii) Adjective-based compounds
$[\operatorname{Adj}+\mathrm{N}]_{\mathrm{N}}$
(iv) Diminutive-based compounds
$[\mathrm{Dim}+\mathrm{N}]_{\mathrm{N}}$
(v) Particle $d \grave{a}$ 'with' compounds
$[d \grave{a}+\mathrm{N}]_{\mathrm{N}}$
(vi) Verb-based compounds
$[\mathrm{V}+\mathrm{VN} / \text { Prep }]_{\mathrm{V}}$

\subsection{Genitive-based compound registers}

Morphologically, the genitive is a bound morpheme that needs to be attached with a free morpheme. There are full $(n a / t a)$ and clipped genitive $(-n /-r)$ in Hausa. The genitive-based compound registers have the following structures:

(1) a.

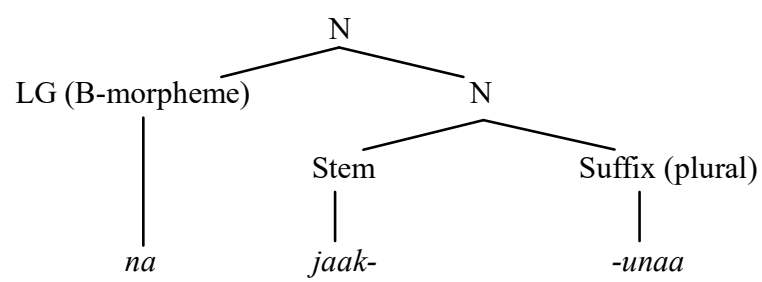

b.

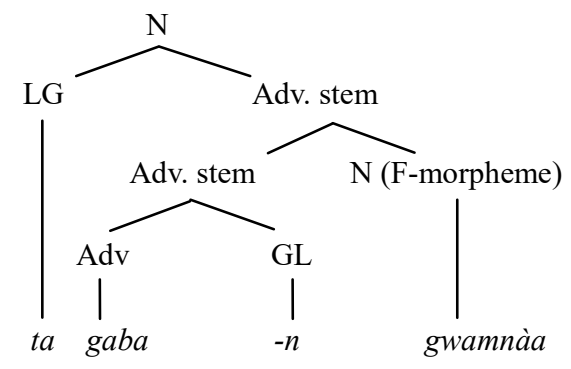


c.

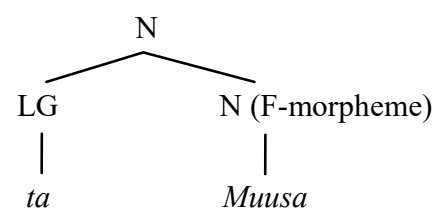

The above three structures $(1 \mathrm{a}-\mathrm{c})$ are the structures of some registers used among Farm-Centre cell-phone marketers that are genitive-based compounds and all of them are nominal compounds. In (1a), the morpheme $n a$, which is the base of the compound na-jaakunàa, is a genitive and a dependent or bound morpheme. It needs to be attached to another bound or free morpheme to have full meaning. However, the word jaakùnaa 'donkeys' is a free or independent morpheme that contains a stem jaak- and a plural suffix morpheme -unaa (singular form: jàakii= jaak $-+-i i$ ). When the two morphemes are attached, there will be a compound noun na-jaakunàa, meaning 'beating'. Grammatically, the word is a noun. The process that has taken place in this compounding is inflection, where one dependent morpheme, which is a functional category and one independent morpheme, which is a noun, combine and form a compound noun. In this case, the grammatical class or category of the independent morpheme does not change. There is only one example found to have the structure explained in (1a) as follows:

na-jaakùnaa (of donkeys, 'beating')

In the language example, the word(s) bracketed without single quotation marks indicate Conventional Meaning, and the word(s) bracketed with the single quotation marks indicate Farm Centre Meaning (the same below).

In (1b), it is also a genitive base compound word with two independent morphemes attached to the base. The genitive is $t a$ - and a dependent morpheme. The genitival linker $-n$ is also a dependent morpheme. While the independent morphemes are gàba 'front', which is an adverb, gwamnàa 'governor' is a noun. The grammatical category of the compound word ta-gaban-gwamnàa 'poverty' is a noun. There are two examples that have the same structure as in (1b) as follows:

na-baayan-tukunyaa (of the back of a pot, 'hidden person'); ta-gaban-gwamna (governor's aid, 'poverty')

In (1c), a long genitive ta-, which is a bound morpheme, is attached to a free morpheme Muusa 'a proper noun' and have a compound word or register ta-Muusa meaning a 'stolen phone'. Below are the thirty-one examples that have the same structure as (1c), with their Hausa conventional meaning and the meaning they bear in the Farm-Centre Cell-phone market.

na-miyàa (of soup/stew, 'police'); na-gwanoo (of a large black stink-ant, 'bad smell'); na-màitubaanii (of a seller of beans-cake, 'judge'); na-àlaikàa (of a greeting, 'shoe'); na-ràagoo (of 
a ram, 'dignity'); na-samà (of higher rank, 'mad man'); na-lawàn (of Lawan (a proper name), 'meat'); na-muujìya (eyes/of owl, 'to put an eye on someone to whatever he/she does'); na-kwattàa (of gutter, 'envy'); na-kaasaa (of snake, 'sleep'); na-màràayuu (orphans' wealth/of orphans, 'cry'); na-gùlàamii (of gulam (an Arabic word, which means a small boy), 'son'); na-faadàa (palace security/of palace, 'trust'); na-danwaakee (of bean's cake, 'fuel'); na-Dikwa (of Dikwa (a town name), 'water'); na-Maanii (of Mani (a proper name), 'female'); na-maniikàa (of a lonely person, 'females'); na-kaurii (very fat/of fat, 'male'); na-kwabè (smudgy, 'getting out'); na-kuura (fear/of hyena, 'fright'); na-Jàmiilaa (of Jamila (a proper name), 'bad smell'); ta-màisàntsii (of smooth person, 'fish'); ta-Màdiinàa (of Medina (a city name), 'lie'); ta-umaraa (ofumrah (the non-mandatory lesser pilgrimage made by Muslims to Mecca, which may be performed at any time of the year), 'lie'); ta-màikiifii (of fish seller, 'penis'); ta-Bulàama (of Bulama (a proper name), 'walk'); ta-Sulèemaanàa (of Sulemana (a proper name), 'phone'); ta-guzàa (of monitor lizard, 'penis'); ta-Siidii (of Sidi (a proper name, 'begging'); ta-màrii (of handcuff, 'car'); ta-Muusa (of Musa (a proper name), 'stolen phone').

\subsection{Noun-based compound registers}

This type of compound structure is by far the most common one in Hausa. There are some compound registers used among Farm-Centre cell-phone marketers that have a noun as their base. The registers are nominal and have the following structures:

(2) a.

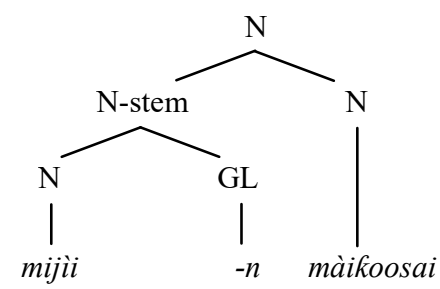

b.

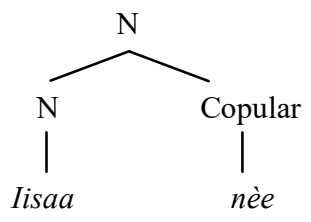

In (2a), the structure is $\mathrm{N}+\mathrm{GL}+\mathrm{Adj}$, where $\mathrm{N}$ stands as mijii, an independent morpheme; $-n$ stands as a genitival linker and a dependent morpheme that needs to be attached to a noun mijii; màikoosai (a noun) is also an independent morpheme. Below are the eight examples that have the same structure as $(2 a)$ with their Hausa conventional meaning and the meaning attached to them in the Farm-Centre Cell-phone market.

mijìn-màikoosai (husband of beans-cake seller, 'police'); gidan-àlbasàa (house of onion, 'prison'); bàakin-wutaa (near fire/mouth of fire, 'fire mouth'); dankan-gòogaa (favourite warrior, 'small amount of money'); awòn-gajancii (measurement of laziness, 'to do an important thing'); 


\section{A Morphological Compounding Analysis of Hausa Registers Use in Nigerian Cell-phone Market}

akwalan-tàku (of an old rag, 'colliding and buying cell-phone'); gajan-amana (lack of trust, 'an old customer'); sadakàr-jiki (giving away a donkey, 'giving yourself out').

Likewise, in (2b), the structure is $\mathrm{N}+$ Copula, where $\mathrm{N}$ stands as Iisaa, an independent morpheme; while nèe is a copula and an independent morpheme. Therefore, there is no change of the grammatical class. Below are the 4 examples that have the same structure as (2b) with their Hausa conventional meaning and the meaning attached to them in the market.

Iisaa-nèe (it is Isa (a male's name), 'customer'); zùngaa-nèe (it is rubbish, 'fake customer'); kertoo-nèe (it is Kerto (a nickname), 'unreliable customer'); washàgarèe-cèe (it is Washagare (a nickname), 'non-profit').

\subsection{Adjective-based compounds}

There are some compound registers used among Farm-Centre cell-phone marketers that have an adjective base. An adjective in those words is an independent morpheme, in which some dependent and independent morphemes are attached to it and form a compound register. If a dependent or an independent morpheme(s) is attached to the adjective base, the grammatical category of the compound word changes. Compound registers that are adjective-based have the following structure:

(3)

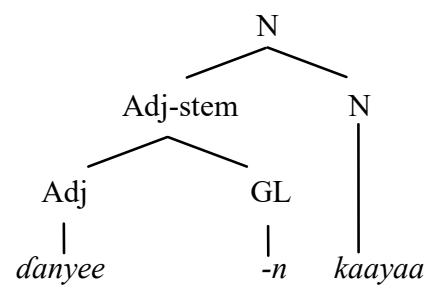

The above structure means that when an adjective is combined with a genitival linker and a noun, the compound register will be a noun. Therefore, the grammatical class of the base will be changed because of the combination of the words with a noun. The word danyee 'fresh' is an adjective, a base of the compound register, and an independent morpheme. The morpheme $-n$ is a genitival linker and a dependent morpheme, which needs to be attached to the base. The word kaayaa 'goods/items' is a noun and an independent morpheme. When all the morphemes are attached, the compound word danyen-kaayaa 'fresh goods/items' will be formed. There are only two registers that have the above structures as follows:

danyen-kaayaa (fresh items/goods, 'stolen phones, ipads and laptop'); doogon-darii (tall Senegalese hartebeest, 'sentenced to prison')

\subsection{Diminutive-based compounds}

In Hausa, "the diminutive comprises the following three items: dan, 'yar and 'yan" (Galadanci, 1976:35). There are some registers used among the Farm-Centre cell-phone 


\section{Almustapha Wali Sambo}

marketers that are diminutive-based. According to Yusuf (2011:41), "diminutive in Hausa occurs with reference to number and gender". Diminutive can be used as a base to have a compound word when attached to a noun, as it was claimed by Yusuf $(2011: 43)^{\mathbb{1}}$ and found in registers used among marketers of cell-phones at Farm-Centre Market. The structure of diminutive-based compound registers is as follows:

(4)

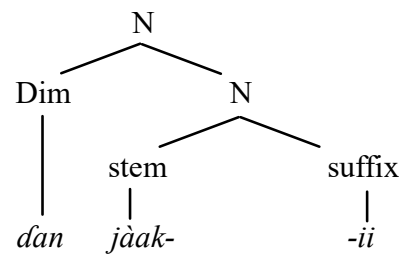

The above structure has dan as a dependent morpheme, which needs to be attached with an independent morpheme jàakii 'donkey' that contains the stem jaak- and a suffix -ii, to form a compound word or a register dan-jàakii. Below are some examples of compound registers that are diminutive-based.

dan-jàakii (son of donkey/little donkey, 'motorcycle'); dan-fitsaarii (son of urine/small urine, 'unreliable customer'); dan-bàabaa (son of a father, 'a wise person in the cell-phone market'); dan-gajàa (son of a fool, 'a dull person in a phone market'); dan-bututu (son of pipe, 'motorcycle'); dan-kwâltaa (son of asphalt, 'a street person (male)'); dan-dambuu (son of food made of flour, 'a good person'); xan-maryaamàa (son of Maryama (a proper name), 'a person who has ideas on cell-phones'); xan-kàbiirù (son of Kabiru (a proper name), 'an emerging wealthy person'); dan-mayàanaa (son of Mayana (a proper name), 'not straight forward person'); 'yar-kwâltaa (daughter of asphalt, 'a street person (female)'); 'yar-gooyoo (daughter of back, 'lesbian'); 'yan-aroo (sons of borrowing, 'thieves')

\subsection{Particle dà compounds}

In this section, some registers used in Farm-Centre Cell-phone Market that have the particle dà 'with' as their base are discovered. The base is a free morpheme that can be attached to another free morpheme (particularly a noun) to form a compound word. They have the following structure:

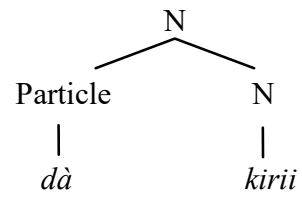

In the above structure, the morpheme dà is a bound morpheme and base of the compound register; while the morpheme kirii 'something' is a free morpheme and a noun.

\footnotetext{
(1) "In short, diminutive has [diminutive+Noun] structure, indicating different types of expression not limited to smallness or littleness (i.e. quantifiers) but can signify so many things."
} 
The following examples are the registers that have the above structure:

dà-kirii (with something, 'there is news'); dà-mâi-dà-yaajìi (type of food, 'to arrest a person')

\subsection{Verb-based compounds}

From the data collected, some registers have a verb base. They are the only exceptions that are not nominal. They are verbal compound registers instead. They have a verb as their base and it is a free morpheme, which can be attached with either a verbal noun or a noun. But the grammatical class of the compound register is a verb. Such compound registers have two structures:

(6) a.

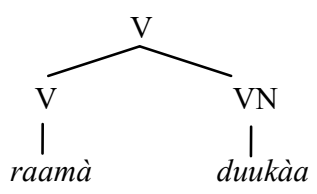

b.

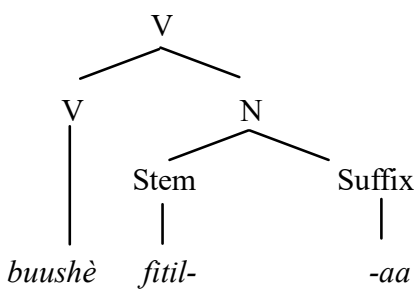

In (6a) and (6b), the verbs are buushèe 'blow-off' and raamàa 'retaliation'. They are the base of the two compound registers and are free morphemes; while duukàa 'beating' is a verbal-noun and fitilàa 'a lamp' a noun. They are also free morphemes. The grammatical class of the base does not change from that of the compound registers. Below are the two examples that have the same structure as (6a) with their Hausa conventional meaning and the meaning attached to them: raamà-duukàa (retaliate beating, 'bad odour'); wankèharkàa (wash something, 'getting profit'). There are four examples below that have the same structure as (6b) with their Hausa conventional meaning and the meaning attached to them.

buushè-fitilàa (blow off a lamp, 'to address a person'); juuyàa-kondà (turn down muscle, 'to turn your back on someone'); taadà-kùuraa (blow up dust, 'to kill'); taashin-kwaanòo (removing roof, 'eating')

\subsection{Discussion of result findings}

From what has been analysed, it is found that the compound registers used by cell-phone marketers at the Farm-Centre Market have six internal compound structures. The structures are: (i) Genitive-based compounds $[\mathrm{LG}+\mathrm{N}]_{\mathrm{N}}$, (ii) Noun-based compounds $[\mathrm{N}+\mathrm{GL}+\mathrm{N}]_{\mathrm{N}}$, (iii) Adjective-based compounds $[\operatorname{Adj}+\mathrm{N}]_{\mathrm{N}}$, (iv) Diminutive-based compounds $[\operatorname{Dim}+\mathrm{N}]_{\mathrm{N}}$, (v) Particle dàcompounds $[d \grave{a}+\mathrm{N}]_{\mathrm{N}}$, and (vi) Verb-based compounds $[\mathrm{V}+\mathrm{VN} / \text { Prep }]_{\mathrm{V}}$. According to Abubakar (2000:77), the noun-based, verb-based and adjective-based 


\section{Almustapha Wali Sambo}

compounds are nominal. Structures (ii), (iii) and (vi) are the structures of compound registers found in the use among cell-phone marketers of Farm Centre Market. The remaining three structures, i.e. (i), (iv) and (v) are also nominal compounds as found in this research because they are non-adverbial compounds; and according to Abubakar (2000:77), there are two major categories of compounds in Hausa. In Hausa, compounds are either nominal or adverbial.

In the data presented and analysed above, there are a total of sixty-nine items or registers, which are all compounds with six different internal structures. Thirty-three compound registers are genitive-based, twelve compound registers are noun-based, two compound registers are adjective-based, fourteen compound registers are diminutive-based, two compound registers are with the particle $d a ̀$, and six compound registers are verb-base. The quantity and percentage of the data analysed and the internal structures of the registers found are summarised in the table below.

Table 1. Number and percentage of the structures of compound registers

\begin{tabular}{c|l|c|c}
\hline S/N & Compound Structure & Quantity of Registers Found & Percentage (\%) \\
\hline 1 & Genitive-based & 34 & 49.3 \\
\hline 2 & Noun-based & 12 & 17.4 \\
\hline 3 & Adjective-based & 02 & 02.9 \\
\hline 4 & Diminutive-based & 13 & 18.8 \\
\hline 5 & Particle dà & 02 & 02.9 \\
\hline 6 & Verb-based & 06 & 08.7 \\
\hline & Total & 69 & 100 \\
\hline
\end{tabular}

The main purpose of the marketers in using such compound registers is to communicate freely without the understanding of the third party, namely, the customers. That is why the compound registers are so special in a way that their meaning is only peculiar to the users (i.e. marketers) and the particular environment (i.e. Farm Centre Cell-phone Market, Kano Metropolis). Meanwhile, for people who do not belong to that particular group of people or vicinity, it is difficult, if not impossible, for them to understand such compound registers in the communication of the marketers. There is also no place or group of people in Kano who speak the same registers. It is, therefore, this peculiarity in meaning that makes those registers different or special.

This study is of significant importance because it tells the structures and meaning of compound registers used by a particular group of Hausa speakers in the metropolis of the centre of commerce in Northern Nigeria. Therefore, the study will be immensely helpful in doing business and communication within such a group of marketers. It will be an additional source of vocabulary in the Hausa language. It will also serve as a reference 
material for sociolinguists and morphologists. It will, of course, serve as a guide to linguists who are interested in the language use and how words are formed in the Farm Centre cell-phone market.

\section{Conclusion}

An attempt is made in this study to explain the morphological processes of compound registers used by Farm Centre cell-phone marketers in Kano State, where certain words and phrases have a different meaning when compared to normal or conventional terms used by native speakers of Hausa language. The ethnographic method of data collection and Abubkar's (2000) model of approach were employed in collecting the data and analysis respectively. From what has been discussed and analysed, it is obvious that the compound registers use among the cell-phone marketers at the Farm Centre Market in Kano have six internal compound structures. The structures are: (i) Genitive-based compounds $[\mathrm{LG}+\mathrm{N}]_{\mathrm{N}}$, (ii) Noun-based compounds $[\mathrm{N}+\mathrm{GL}+\mathrm{N}]_{\mathrm{N}}$, (iii) Adjective-based compounds $[\mathrm{Adj}+\mathrm{N}]_{\mathrm{N}}$, (iv) Diminutive-based compounds $[\mathrm{Dim}+\mathrm{N}]_{\mathrm{N}}$, (v) Particle $d \grave{a}$ compounds $[d \grave{a}+\mathrm{N}]_{\mathrm{N}}$, and (vi) Verb-based compounds $[\mathrm{V}+\mathrm{VN} / \mathrm{Prep}]_{\mathrm{V}}$. However, the registers are so special among the marketers because they convey meaning that is irrelevant to the conventional meaning, which is known by the general Hausa speakers. The compound registers are added into the Hausa lexicon, which have not been used before or in somewhere that is not Farm Centre Cell-phone Market. Therefore, the registers could be of benefit to the marketers in doing their businesses and specifically to their use of the Hausa language.

\section{Abbreviations}

$\begin{array}{ll}\text { A } & \text { adjective/adverb } \\ \text { Adj } & \text { adjective } \\ \text { Adv } & \text { adverb } \\ \text { B-morpheme } & \text { bound morpheme } \\ \text { Dim } & \text { diminutive } \\ \text { F-morpheme } & \text { free morpheme } \\ \text { GL } & \text { genitival linker } \\ \text { L } & \text { link }\end{array}$

$\begin{array}{ll}\text { LG } & \text { long genitive or full genitive } \\ \text { N } & \text { noun } \\ \text { Prep } & \text { preposition } \\ \text { V } & \text { verb } \\ \text { VN } & \text { verbal noun } \\ \text { X } & \text { unspecified word/morpheme } \\ \text { Y } & \text { unspecified word/morpheme }\end{array}$

\section{References}

Abraham, R. C. 1941. A Modern Grammar of Spoken Hausa [M]. London: Crown Agents for the Colonies.

Abubakar, A. 2000. An Introductory Hausa Morphology [M]. Nigeria: University of Maiduguri.

Ahmad, M. 1994. Aspects of Hausa Compounding [D]. Ph.D. Dissertation, Bloomington: Indiana University.

Galadanci, M. K. M. 1969. The Simple Nominal Phrase in Hausa [D]. Ph.D. Dissertation, London: London University.

Galadanci, M. K. M. 1972. The Structure and Syntactic Function of Compound Nouns in Hausa [J]. Anthropological Linguistics, 14:147-154. 


\section{Almustapha Wali Sambo}

Galadanci, M. K. M. 1976. An Introduction to Hausa Grammar [M]. Ikeja: Longman Nigeria Group Limited.

Gouffé, C. 1965. La Lexicographie du Haoussaet le Préalable Phonologique [J]. Journal of African Languages, 4(3):191-210.

Ferguson, C. A. 1994. Dialect, Register, and Genre: Working assumptions about conventionalization [A]. In D. Biber \& E. Finegan (eds.), Sociolinguistic Perspectives on Register [C]. Oxford: Oxford University Press, $15-30$.

Jaggar, P. J. 2001. Hausa [M]. Amsterdam: John Benjamins.

McIntyre, J. A. 2006. Hausa Verbal Compounds [D]. Ph.D. Dissertation, The University of Leipzig.

Newman, P. 2000. The Hausa Language: An encyclopedic reference grammar [M]. New Haven: Yale University Press.

Spencer, A. 1991. Morphological Theory: An introduction to word structure in generative grammar [M]. Oxford: Blackwell Publishers.

Wardhaugh, R. 2006. An Introduction to Sociolinguistics (5th edition) [M]. Oxford: Blackwell Publishers.

Yule, G. 2010. The Study of Language (4th edition) [M]. New York: Cambridge University Press.

Yusuf, M. A. 2011. Hausa Grammar: An introduction [M]. Zaria: Ahmadu Bello University Press Limited. 